\title{
Aldo Indelicato: il M.A.C. siciliano e la connessione tra le arti
}

\author{
Michela De Domenico
}

Abstract

Nell'agitarsi di energie del secondo dopoguerra italiano, nasce il M.A.C. Movimento Arte Concreta. L'arte concreta attinge a forme, linee e colori elaborati in maniera autonoma dallimmaginazione dell'artista, alla ricerca di forme pure, primordiali, che si sviluppano attraverso la materia e il colore senza alcuna possibile analogia con il mondo naturalistico. Questa ricerca di purezza formale confluisce in un inedito linguaggio espressivo che fonde architettura, pittura, scultura: la 'sintesi delle arti'. II Movimento per l'Arte Concreta sbarca in Sicilia per una fase molto breve, dal 1953 al 1958, attraverso il MAC di Catania, i cui maggiori esponenti sono lo scultore Dino Caruso, il pittore Michele Santonocito e l'architetto Aldo Indelicato. Indelicato e Caruso costituiranno un affiatato sodalizio artistico che darà vita a diverse opere rientranti nell'ambito del MAC. Tra queste il progetto del cinema Metropol a Messina, rappresenta l'opera che più esprime quell'idea di 'arte totale', che in Sicilia assorbe anche istanze legate all'artigianato e alla tradizione delle arti applicate. Il progetto abilmente giocato tra la purezza formale dell'esterno e il ritmo dell'interno, presenta elaborazioni pittoriche e inserti in ceramica che si integrano all'architettura riuscendo a coniugare i temi dell'arte totale e della sintesi delle arti, tanto cari al MAC.

Parole chiave

sintesi, arte, architettura, designer, arte applicata.

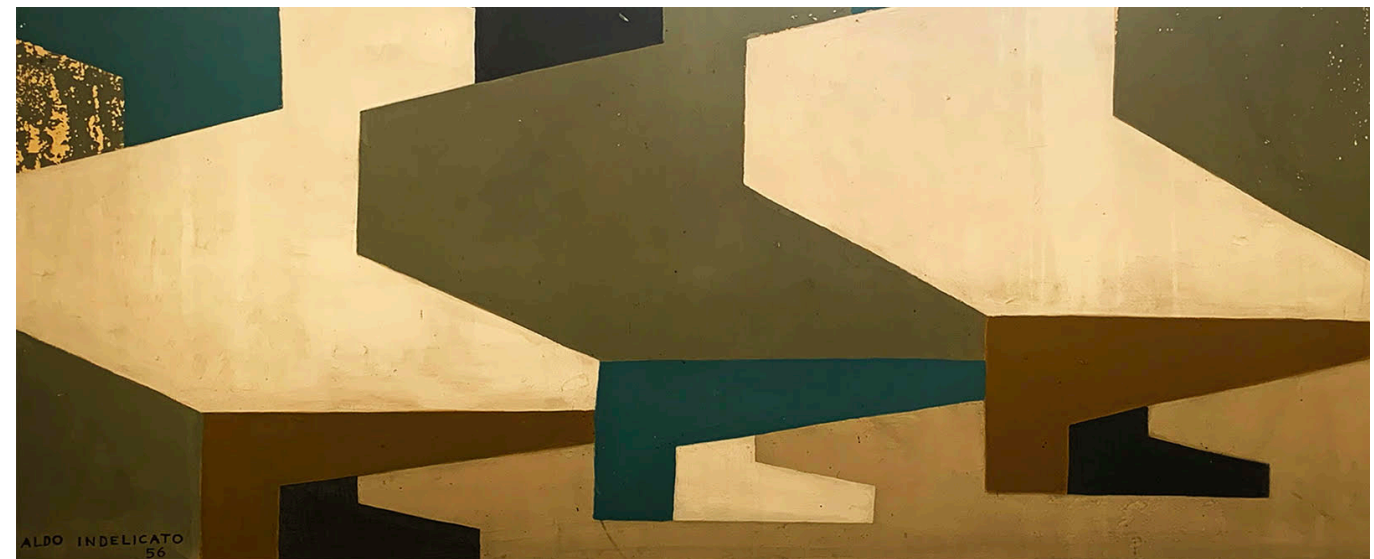




\section{L’esperienza del M.A.C.}

Nell'agitarsi di energie proprio del secondo dopoguerra italiano, in cui si mescolano richieste di innovazione ed istanze sociali e politiche, nasce il M.A.C. Movimento Arte Concreta, che, ripartendo idealmente da quel concretismo proposto negli anni trenta da Kandinskij e Van Doesburg, si propone il rinnovamento, la sprovincializzazione e l'individuazione di nuove prospettive per l'arte, in linea con le ricerche internazionali. L'occasione è la mostra presso la libreria Salto di Milano nel dicembre 1948, in cui vengono esposte 12 "stampe a mano" firmate da Gillo Dorfles, Bruno Munari, Gianni Monnet, Atanasio Soldati, fondatori del movimento e Piero Dorazio, Augusto Garau, Giovanni Guerrini, Galliano Mazzon, Achille Perilli, Luigi Veronesi, Ettore Sottsass e Lucio Fontana (fig. I).

II gruppo è formato da quei pochi artisti che avevano rifiutato in toto la tradizione del Novecento Italiano, non avevano accettato le attitudini artistiche e ideologiche del realismo sociale e il cui comune obiettivo era quello di promuovere l'arte non figurativa, un libero astrattismo di orientamento prevalentemente geometrico. Ma il MAC supera anche l'idea di un certo astrattismo, ponendosi contro l'irrazionalità dell'informale e concentrandosi sulla sperimentazione concreta con il fine del raggiungimento di una sintesi delle arti. Questa ricerca legata alla sperimentazione fa si che gli stessi artisti del MAC, pittori, architetti, scultori, realizzino ricerche molto diverse tra loro, con denominatore comune il desiderio di innovare e sperimentare. Ben presto, da Milano, il movimento diventa un centro di propulsione per lo sviluppo dell'arte e amplia la propria attività costituendo nuovi gruppi in diverse città italiane, come Genova, Torino, Firenze, Roma, Napoli, Catania e si allaccia, più tardi, all'esperienza francese del Groupe Espace.

Gillo Dorfles, che con Bruno Munari si impone come teorico del movimento, nel manifesto del 195I indica la prassi creativa dell'arte concreta, che piuttosto che basarsi su procedimenti di astrazione di immagini tratte dalla natura, attinge a forme, linee e colori elaborati in maniera autonoma dall'immaginazione dell'artista, alla ricerca di forme pure, primordiali, che si sviluppano attraverso la materia e il colore senza alcuna possibile analogia con il mondo naturalistico. Questo processo, che spesso si sviluppa indifferentemente dalla finalità dell'oggetto, inizia dalla configurazione del modulo grafico, che parte dall'elaborazione di semplici

Fig. I. Foto di gruppo dei membri del M.A.C alla libreria Salto di Milano. Veronesi, Salto, Munari, Di Salvatore, Mazzon, Soldati, Regina, Giulia Mazzon Sala, Monnet, Dorfles, 1951 (fotocollage di Monnet).

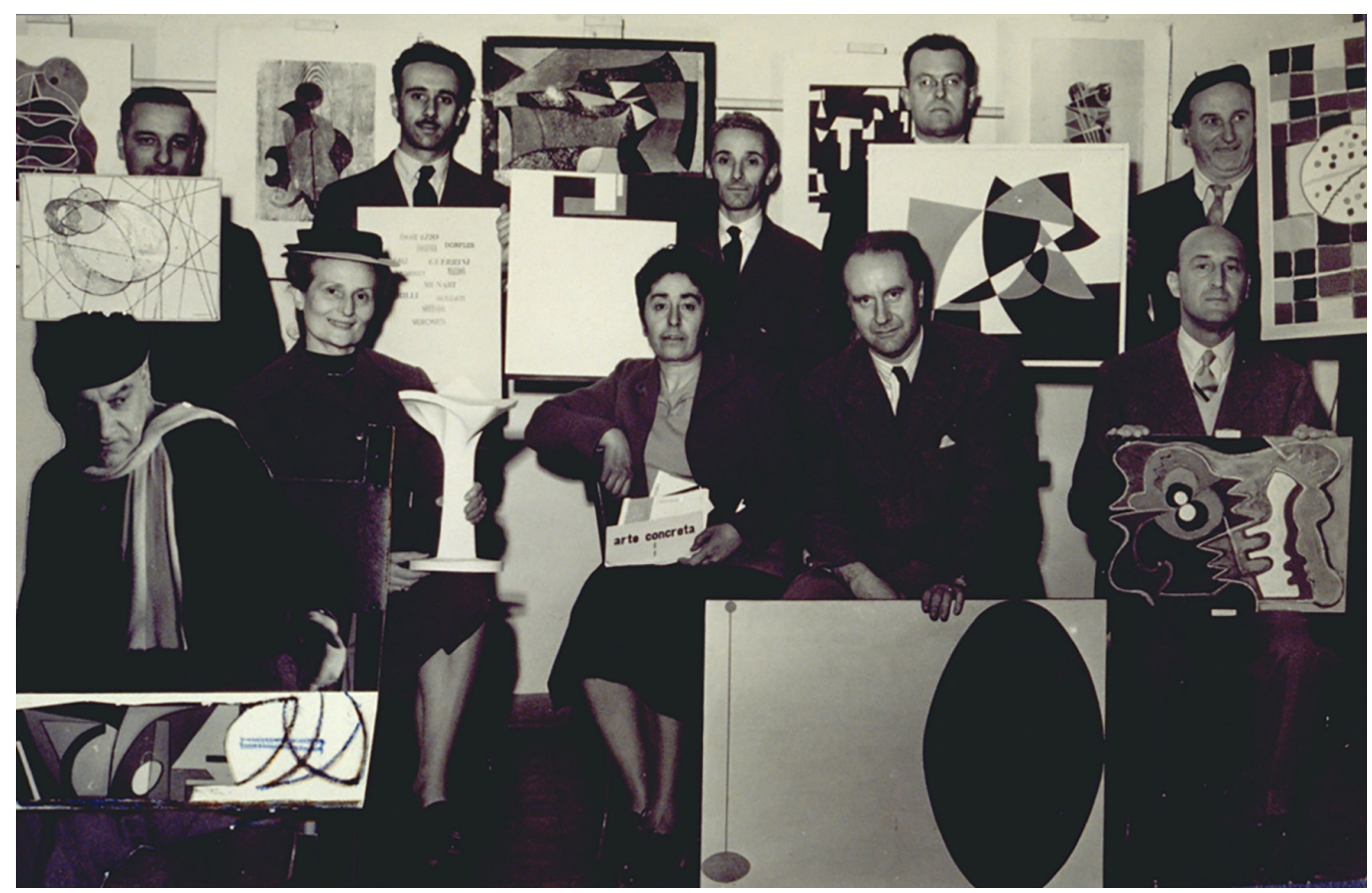




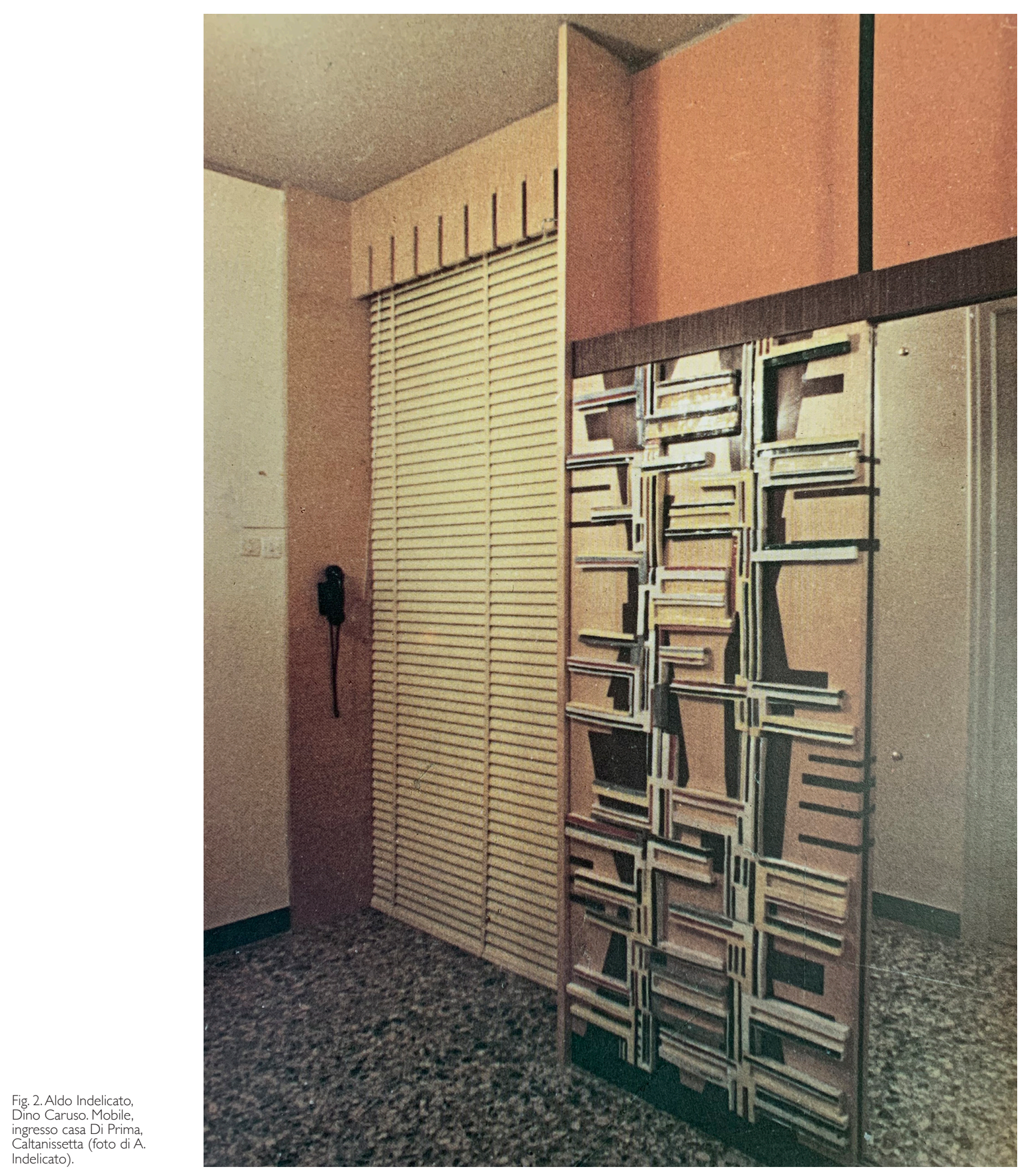


e schiette figure geometriche, quadrati, losanghe, triangoli, o di altri segni, estrapolati anche dalla cosiddetta arte decorativa e dal successivo sviluppo attraverso il cromatismo, il contrappunto cromatico, e il ritmo compositivo, che vengono a costituire il centro formativo dell'opera d'arte [I]. Questa ricerca di purezza formale confluisce in un inedito linguaggio espressivo che fonde architettura, pittura, scultura: la 'sintesi delle arti'. Carlo Perogalli, architetto fondatore del MAC, in linea con le definizioni di Andrè Bloc del Groupe Espace, parla di un'aspirazione dell'arte concreta all'espressione unitaria, per la quale è d'obbligo che l'artista assommi in sé le personalità dell'architetto, dello scultore, del pittore [2], oppure, secondo la definizione di Franco Passoni essere "il diretto concorso di tecnici e artisti, sul piano della stretta collaborazione, per il raggiungimento di un Concreto il quale aderisce alla Funzione in armonia e colleganza tra il mondo della forma, lo spazio nell'applicazione pratica dell'opera collettiva" [Indelicato Aldo 1998, p. I4] [3]. Come nel Liberty, questa commistione coinvolge anche le arti applicate, ceramica, plastica, grafica, tessitura, allestimenti, ma mentre nello stile floreale, architettura e decorazione restano slegate, nel MAC, l'arte applicata, in concorso con le tre arti maggiori, contribuisce alla creazione del corpus unitario dell'opera totale. Si riscopre così anche la funzione di sintesi tra artista e artigianato che solo temporaneamente era stata interrotta, da un lato, mentre dall'altro si sviluppa la figura del designer formulata da Munari, intimamente legata, più che alla figura dell'artista, a quella dell'architetto, poiché più pragmatica e disposta all'innovazione tecnologica.




Nella seconda fase della propria esistenza, nel 1955, il MAC si unirà, come movimento concretista italiano, al francese Groupe ESPACE con l'obiettivo di ampliare il discorso dell'arte totale ad un'area e ad implicazioni culturali più estese. La parabola del MAC sarà breve e si concluderà nel 1958, ma la sua influenza resterà tangibile negli sviluppi dell'arte successiva.

\section{MAC siciliano}

Estendendosi in pochi anni a tutta la penisola italiana, il Movimento per l'Arte Concreta sbarca in Sicilia per una fase molto breve, dal 1953 al 1958, costituendosi come MAC di Catania, anche se in un primo momento comprende anche Palermo. II gruppo è guidato da Gesualdo (Dino) Caruso, scultore, pittore e ceramista originario di Caltagirone, che avendo frequentato assiduamente lo studio dell'amico Enrico Prampolini, durante gli anni del suo soggiorno romano, avvia contatti con Munari e Monnet, i quali lo inseriscono ben presto nel MAC. Infatti, assieme ad altri artisti siciliani, Caruso partecipa nel 1953 alla mostra del MAC, Collezione ambientata, nello Studio b-24 di Milano e le sue opere vengono pubblicate sul bollettino Arte concreta assieme a quelle di Mirone, Santonocito, Signorelli e Teghini. Più avanti si uniscono a questo gruppo gli architetti Aldo Indelicato e Corrado D'Urso nonché l'ingegnere Salvatore Costa. II MAC di Catania è poco dopo presente alla mostra del MAC/ Espace, alla galleria del Fiore di Milano nel 1955 e alle altre attività del gruppo nazionale, oltra a realizzare esposizioni a livello locale, fino all'ultima mostra del 1957 alla galleria Schettini di Milano, quest'ultima limitatamente alla presenza del fondatore Caruso. Coloro che più di altri intesero e portarono avanti le istanze del MAC furono però, oltre Caruso, il pittore Michele Santonocito e l'architetto Aldo Indelicato, assieme al quale lo stesso Caruso costituirà un affiatato sodalizio artistico (fig. 2).

II MAC siciliano si colloca in un'ideale continuità con il movimento futurista siciliano sia per il suo porsi contro il figurativismo, sia per la riscoperta dell'artigianalità [4]. Si caratterizza nel porre l'interesse sulla qualità dell'architettura ed in particolare sulla sperimentazione di una sintesi delle arti che possa essere occasione per nuovi segni urbani, in cui il gusto per il disegno si sublima nella sintesi di aspetti tecnologici formali e nel piacere del progetto che si fa veicolo di arte e cultura creativa dei luoghi.

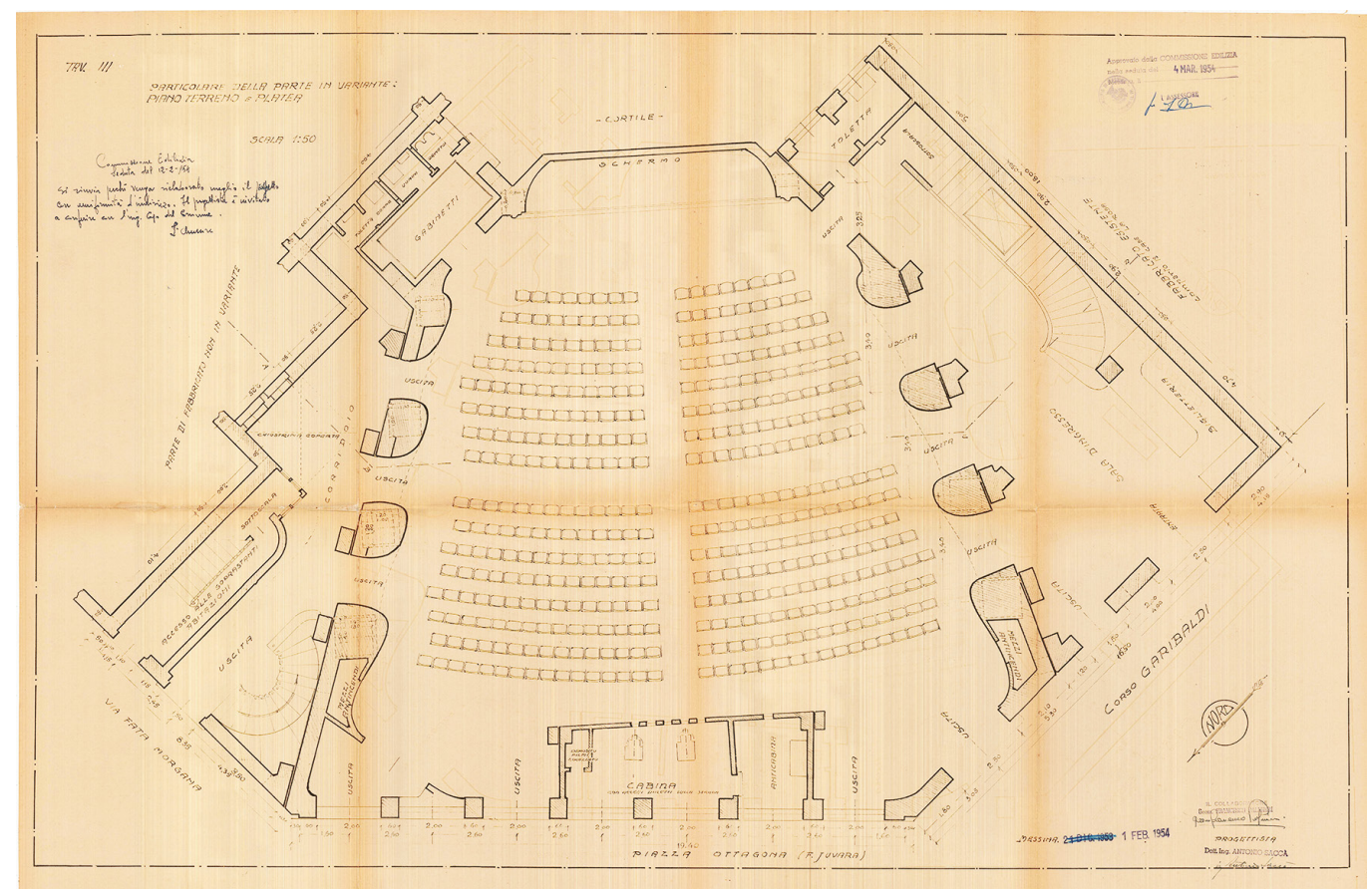




\section{La connessione delle arti di Aldo Indelicato}

Aldo Indelicato nasce a Messina nel 1927, studia architettura con Roberto Pane e Ludovico Quaroni nelle facoltà di Venezia e di Napoli, dove si laurea nel 1952. Nella sua lunga attività professionale collabora con figure di spicco dell'architettura contemporanea come Rovigo, Quaroni, Scarpa e Calandra. Con Giuseppe Samonà avvia una collaborazione che dura anni e che lo vede cooperare alla costruzione di diversi edifici della palazzata di Messina. Risale al 1953, subito dopo la laurea, l'adesione al MAC siciliano assieme a Michele Santonocito e Dino Caruso. Con quest'ultimo forma un sodalizio che darà vita a diversi progetti: una villa a Sant'Alessio, in provincia di Messina, il palazzo di piazza Santa Maria di Gesù a Catania e il cinema Metropol di Messina.

Indelicato è interprete raffinato e aperto alle correnti europee più avanzate di arte contemporanea e le sue architetture sono opere-simbolo di quel purismo formale che sta alla base della 'sintesi delle arti' (fig. 3). Per Indelicato l'opera nasce da una visione assieme materica, plastica, pittorica che diventa spazio e forma architettonica, lungi dal decorativismo, sperimentando nuove soluzioni, sia sul piano dell'uso della forma-spazio, sia sul piano del rapporto struttura-decorazione dell'architettura di esterni interni [5]. Nell'esperienza col MAC, Indelicato ha le idee molto chiare sul significato di concretismo e di opera totale: la sua collaborazione con Caruso si struttura in questo ambito con l'intento principale di perseguire una sintesi tra progetto architettonico e arti applicate, nel recupero della artigianalità dell'arte ceramica, plastica e pittorica [6]. In questo percorso egli si pone in continuità con una solida tradizione che, a Messina, legava l'architettura all'artigianato e che passava dalla Regia Scuola d'Arte e Mestieri, che a cavallo tra '800 e '900 assimila il passaggio al Liberty, alle scuole di arte applicata formatesi in Sicilia col Futurismo, la cui globalità di interessi coinvolgeva la ceramica, la pittura e l'arazzo. In questa contiguità egli tende a riproporre il

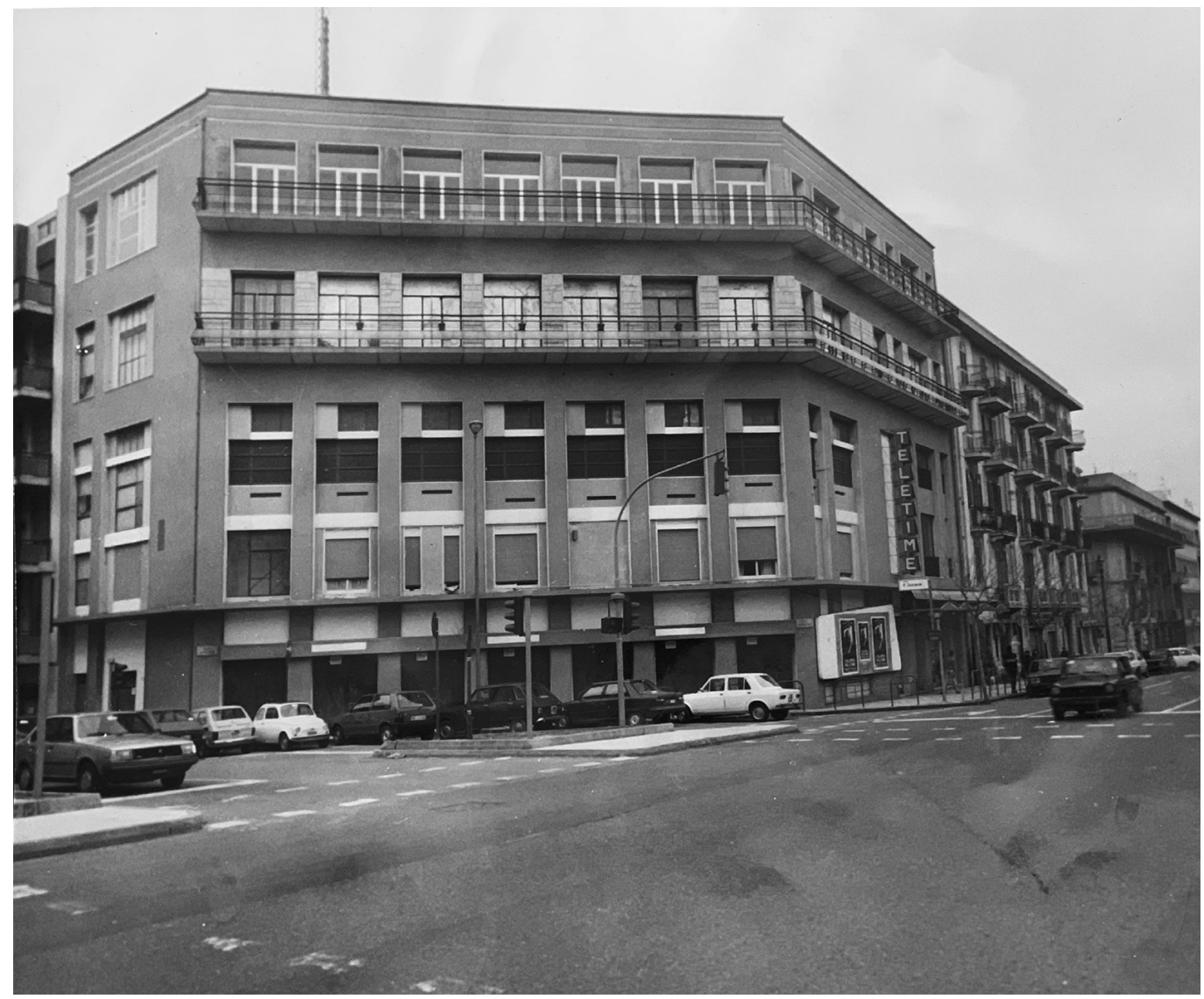


ruolo di "maestro d'arte", più che la figura del designer ed afferma criticamente:"Munari - e quelli che avevano un analogo modo di impostare criticamente e operativamente la sintesi delle arti, tendendo all'arte totale' - erano convinti che l'operatore più intimamente legato al mondo dell'architetto fosse il designer e non l'artista" [Sartori 1998, p. I2] [7]. Si potrebbe dire che tra le due anime del MAC, quella artistica legata all'astrattismo e all'irrazionalità dell'arte, che ha come punto di riferimento Prampolini e quella più intimamente legata all'architettura e alla figura del designer, tanto cara a Munari, Indelicato, pur avvicinandosi all'ambito di quest'ultima, sembri scegliere una terza strada, quella dell'architetto artigiano. La sua opera si colloca così in una dimensione assieme progettuale e artistica, che avrà un ultimo spunto progettuale nella Casa sperimentale, realizzata in collaborazione con Ravegnani, Vincenti e Brunori.

Anche dopo lo scioglimento del MAC, Indelicato resterà coinvolto nella visione artistica promulgata dal gruppo [8], che lo porta ad intraprendere nelle sue opere, strette collaborazioni con altri artisti siciliani come Felice Canonico, Francesco Finocchiaro, Vincenzo Cacopardo, Mario Lucerna, il maestro artigiano Leuzzi. II connubio tra progettualità e artigianalità sarà anche alla base della nascita nel 1954 dell'Istituto Statale d'Arte di Messina, fondato da Salvatore Castagna, che dirige nel periodo compreso tra il 1967 ed il 1983 e con il contributo del quale realizzerà diverse mostre sul design.

\section{Il cinema Metropol, un esempio di sintesi delle arti}

L'intervento sul cinema Metropol di Messina, realizzato nel 1956, rientra in quei dettami di sintesi delle arti auspicati dal MAC, in cui l'architettura di Aldo Indelicato e la scultura di Dino Caruso si coniugano.

II progetto dell'edificio, presente negli archivi del Comune di Messina al fascicolo 19//I sotto la ditta Cinema Fata Morgana, è firmato dall'ing. Antonio Saccà e approvato dalla

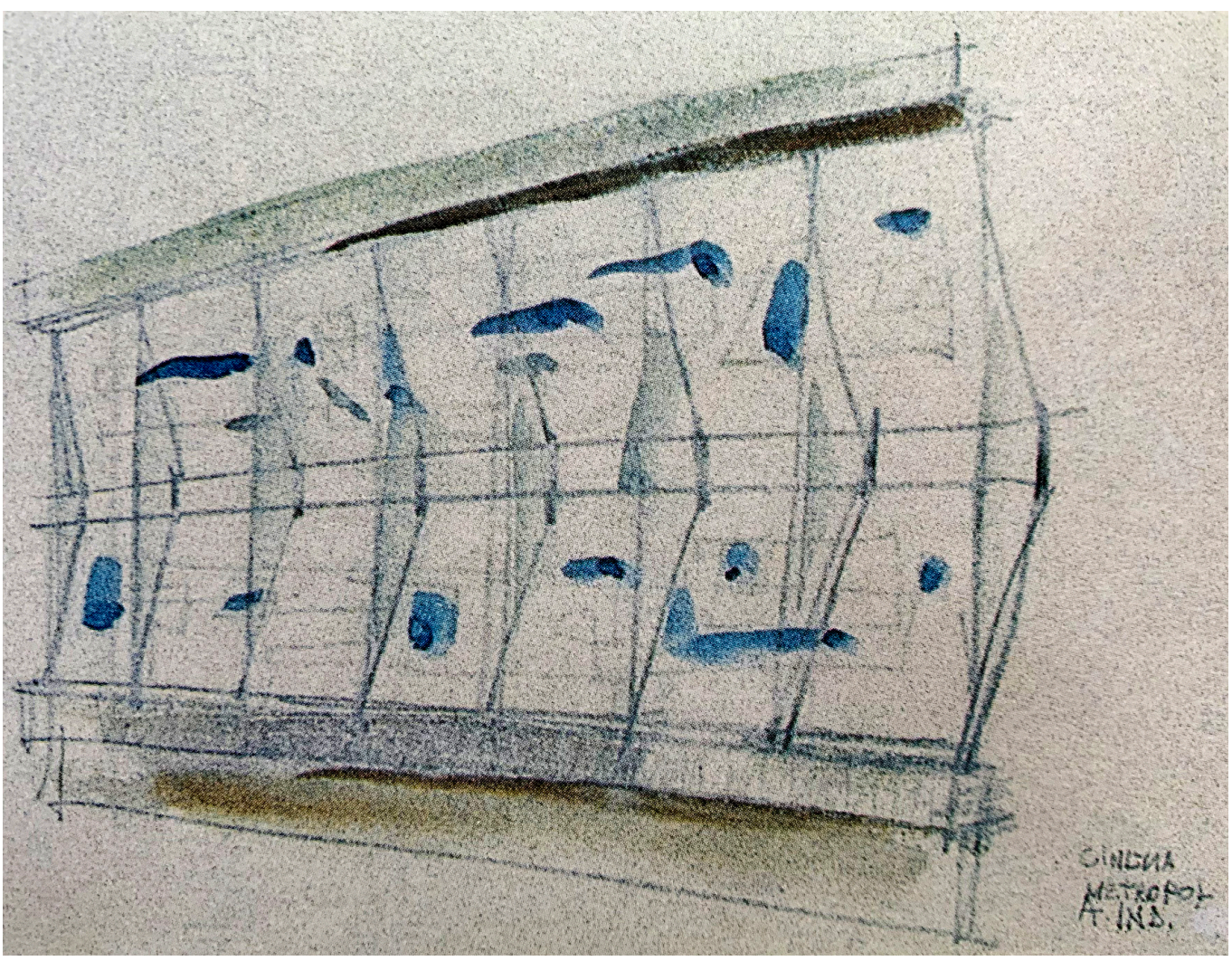




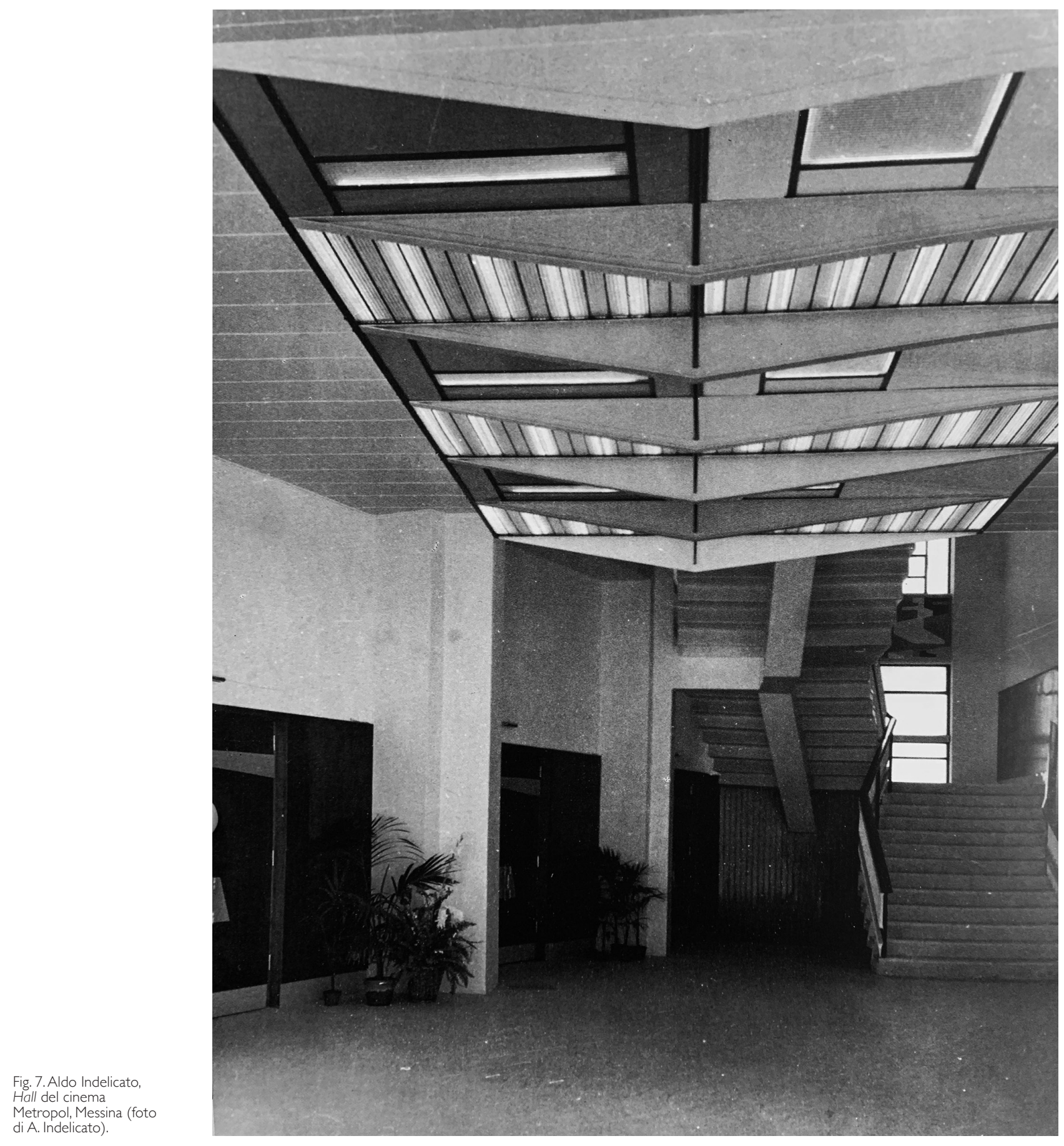


Commissione Edilizia nel 1954 (fig. 4). Ubicato su uno dei lati che perimetrano piazza Juvara, l'antica piazza Ottagona di cui conservava l'impronta, il progetto del cinema prevede la soppressione dell'originaria particella residenziale e la sostituzione con un edificio di cinque piani fuori terra, che rompe l'unitario skyline della piazza. All'esterno, la purezza formale della facciata riporta a forme astratte e rigorose, intagliate in verticale dall'inserimento di bucature a doppia altezza, in corrispondenza della tribuna del cinema, mentre i segni orizzontali sono sottolineati dall'effetto chiaroscurale della cornice aggettante al primo livello, dai due balconi continui su due dei tre lati esterni, posti al quarto e al quinto livello e dal coronamento in pietra artificiale (fig. 5).



L'intervento di Indelicato e Caruso all'interno dell'edificio, crea una sintesi artistica che sembra contraddire il rigore dell'esterno, accentuata dal dinamismo della forma trapezoidale della pianta. II connubio tra architettura, pittura e scultura, qui coinvolge anche l'arte applicata che permea gli ambienti interni del cinema, trovando i vertici più elevati di espressione artistico-architettonica, nelle soluzioni del controsoffitto dell'ingresso e di quello ligneo della tribuna, nella decorazione del volume della cabina di proiezione e nella zona laterale allo schermo (figg. 6-8). É lo scultore calatino a realizzare le decorazioni della tribuna e gli inserti in ceramica ai lati dello schermo, senza tralasciare le applicazioni decorative su porte, scale 
Fig. 9. Aldo Indelicato, Dino Caruso, tribuna e cabina di proiezione del cinema Metropol, Messina (foto di A Indelicato).



e pareti (fig. 9), mentre Indelicato si occupa degli inserti pittorici presenti ai lati dello scalone che porta alla tribuna (fig. I0). Egli è consapevole che "il persistere del ruolo decorativo degli interventi di Caruso [...] significava sperimentare consapevolmente soluzioni divergenti dai dettami dell' "architettura totale"' [Berni Canani 1999, p. 12] [9] e forse proprio in questo il MAC siciliano si differenzia dagli altri movimenti. Dai disegni per la tribuna si evidenzia il modus operandi di Aldo Indelicato, che partendo da forme geometricamente rigorose, rese in concrete immagini di forma-colore, mira a cogliere ritmi, cadenze e accordi cromatici, che si trasformano in segni dinamici e plastici (fig. I I). II progetto, giocato tra la purezza formale dell'esterno e il ritmo interno, riesce a coniugare i temi dell'arte totale e della sintesi delle arti, tanto cari al MAC.

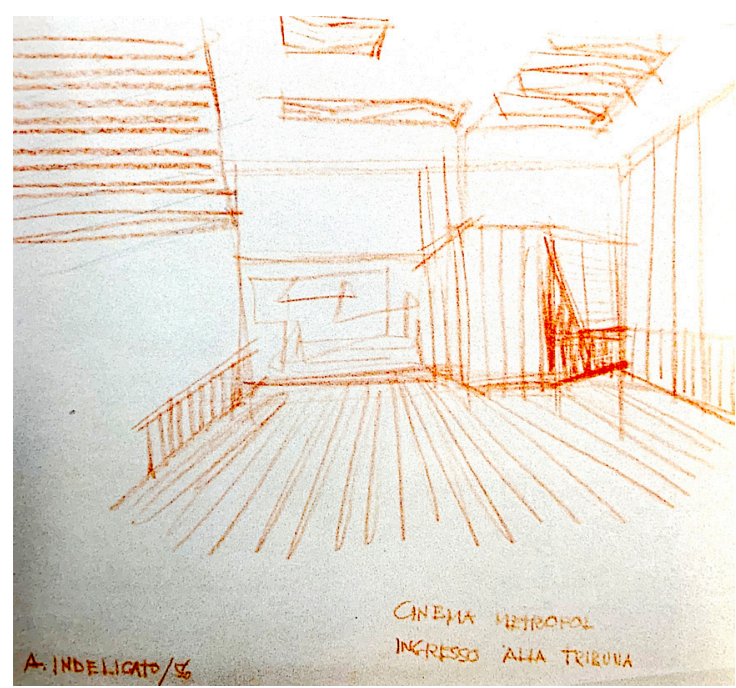




\section{Note}

[I] Di Genova Giorgio ( 1999). L'arte concreta e l'utopia della sintesi delle arti in Francia ed in Italia. In Berni Canani, Di Genova 1999, p. 24.

[2] Perogalli Carlo, architetto del MAC, scrive "ove non siano più distinguibili architettura, pittura, scultura quali elementi giustapposti, sovrapposti, sommati, ma dove essi si concretizzino in espressione unitaria". Pertanto, per la sua realizzazione, sarà necessario un unico "artista che assommi in sé le personalità dell'architetto, dello scultore, del pittore, o la intima collaborazione di più artisti": Caterina Sartori ( 1998). II M.A.C. In Ordine degli Architetti della provincia di Messina (a cura di). Architettura e design nell'area dello Stretto. Spunti di ricerca, p. 14.

[3] Indelicato Aldo (1998). Materiali per la storia del M.A.C. siciliano. In Dorfles, Indelicato I998. p. I4.

[4] Berni Canani Luciano (a cura di). (1999). “Intervista ad Aldo Indelicato”. In Berni Canani, Di Genova I999, p. 49.

[5] Romeo Carmelo ( 1998). Aldo Indelicato: un percorso tra design e sintesi delle arti. In Sartori 1998, p. 23.

[6] Di Genova Giorgio (1999). La propaggine di Catania. In Berni Canani, Di Genova 1999, p. 102.

[7] Sartori Caterina (1998). II M.A.C. In Architettura e design nell'area dello Stretto. In Ordine degli Architetti della Provincia di Messina (a cura di) Architettura e design nell'area dello Stretto. Spunti di ricerca. Messina: Ordine Architetti Messina. p. I2.

[8] Indelicato Aldo (1998). Materiali per la storia del M.A.C. siciliano. In Dorfles, Indelicato 1998. p. 9.

[9] Berni Canani Luciano (a cura di). (1999). Intervista ad Aldo Indelicato. In Berni Canani, Di Genova 1999. p. 49.

\section{Riferimenti bibliografici}

Berni Canani Luciano, Di Genova Giorgio (a cura di). (1999). MAC/Espace: arte concreta in Italia e in Francia 1948-1958. Bologna: Bora.

Cucinotta Francesca (201 I). Suggestioni sintetiste a Messina negli anni cinquanta e sessanta: dal MAC a Felice Canonico. In Città \& Territorio, 5, pp. 36-4l.

Dorfles Gillo, Indelicato Aldo (a cura di). (1998). Il MAC siciliano e la sintesi delle arti. Messina: Cartescritture.

Dorfles Gillo (2003). Ultime tendenze dell'arte d'oggi. Milano: Feltrinelli.

Indelicato Aldo (1999). Architettura e dintorni: spunti per una riflessione sulla "Sintesi delle Arti" nella città di Messina. In Città \& Territorio, I, pp. 46-50.

Indelicato Aldo (200 I). Decadenza e risveglio delle Arti applicate a Messina. In Città \& Territorio, 6, pp. 34-37.

Ordine degli Architetti della Provincia di Messina (a cura di). (1998). Architettura e design nell'area dello Stretto. Spunti di ricerca. Messina: Ordine Architetti Messina.

Autore

Michela De Domenico, Università di Messina, micheladedomenico@gmail.com

Per citare questo capitolo: De Domenico Michela (2020). Aldo Indelicato, il M.A.C. siciliano e la connessione tra le arti/Aldo Indelicato, the Sicilian M.A.C. and the Connection between the Arts In Arena A., Arena M., Brandolino R.G., Colistra D., Ginex G., Mediati D., Nucifora S., Raffa P. (a cura di). Connettere. Un disegno per annodare e tessere. Atti del $42^{\circ}$ Convegno Internazionale dei Docenti delle Discipline della Rappresentazionel Connecting. Drawing for weaving relationships. Proceedings of the 42th International Conference of Representation Disciplines Teachers. Milano: FrancoAngeli, pp. 368-389. 


\title{
Aldo Indelicato: the Sicilian M.A.C. and the Connection between the Arts
}

\author{
Michela De Domenico
}

\section{Abstract}

In the agitation of energies of the Italian Post-War II, the M.A.C. Movimento Arte Concreta (Movement of Concrete Art) was born. Concrete Art draws on shapes, lines and colors independently elaborated by the imagination of the artist, in search of pure, primordial forms, which develop through material and color without any possible analogy with the naturalistic world. This search for formal purity is a new expressive language that blends architecture, painting and sculpture: the 'synthesis of the arts'. The Movimento Arte Concreta arrives in Sicily for a very short phase, from 1953 to 1958 , through the MAC of Catania, whose main exponents are the sculptor Dino Caruso, the painter Michele Santonocito and the architect Aldo Indelicato. Indelicato and Caruso will form a close-knit artistic partnership that will give life to several works within the framework of the MAC. Among these, the project of the Metropol cinema in Messina, represents the work that most expresses that idea of 'total art', which in Sicily also absorbs instances related to the craftsmanship and tradition of the applied arts. The project cleverly played between the formal purity of the exterior and the rhythm of the interior, presents pictorial elaborations and ceramic inserts that integrate with the architecture managing to combine the themes of total art and the synthesis of the arts, so dear to MAC.

Keywords

synthesis, art, architecture, designer, applied art.

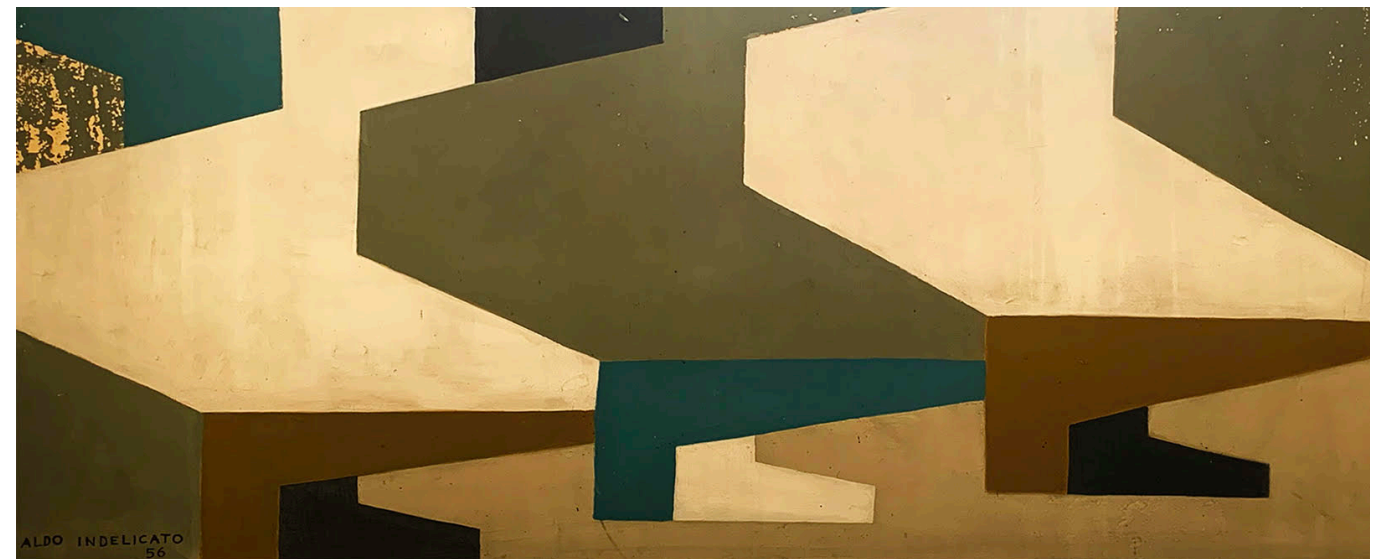




\section{The M.A.C. experience}

In the agitation of energies of the Italian Post-War, in which are mixed requests for innovation and social and political demands, the M.A.C. Concrete Art Movement was born, which, ideally starting from that concretism proposed in the 1930s by Kandinsky and Van Doesburg, proposes renewal, deprovincialization and the identification of new perspectives for the art, in line with international research. The occasion is the exhibition at the Salto bookstore in Milan in December 1948, in which 12 "hand prints" signed by Gillo Dorfles, Bruno Munari, Gianni Monnet, Atanasio Soldati, founders of the movement and Piero Dorazio, Augusto Garau, Giovanni Guerrini, Galliano Mazzon, Achille Perilli, Luigi Veronesi, Ettore Sottsass and Lucio Fontana (fig. I).

The group is formed by those few artists who had completely rejected the tradition of the twentieth century Italian, had not accepted the artistic and ideological attitudes of social realism and whose common goal was to promote non-figurative art, a free abstraction of predominantly geometric orientation. But the MAC also overcomes the idea of a certain abstraction, pitting itself against the irrationality of the informal and focusing on concrete experimentation with the aim of achieving a synthesis of the arts. This research linked to experimentation means that the same artists of MAC, painters, architects, sculptors, carry out their own researches very different from each other, with common denominator the desire to innovate and experiment. Soon, from Milan, the movement becomes a propulsion center for the development of art and expands its activity by constituting new groups in different Italian cities, such as Genoa, Turin, Florence, Rome, Naples, Catania and later connects to the French experience of the Groupe Espace.

Gillo Dorfles, who with Bruno Munari imposes himself as a movement theorist, in the 1951 manifesto indicates the creative practice of concrete art, rather than relying on abstraction procedures of images taken from nature, drawing and forms, lines and colors independently elaborated from the artist's imagination, in search of pure forms, they develop through matter and color without any possible analogy with the naturalistic world. This process, which often develops indifferently to the purpose of the object, begins with the configuration of the graph module, which starts from the elaboration of simple and outspoken geometric

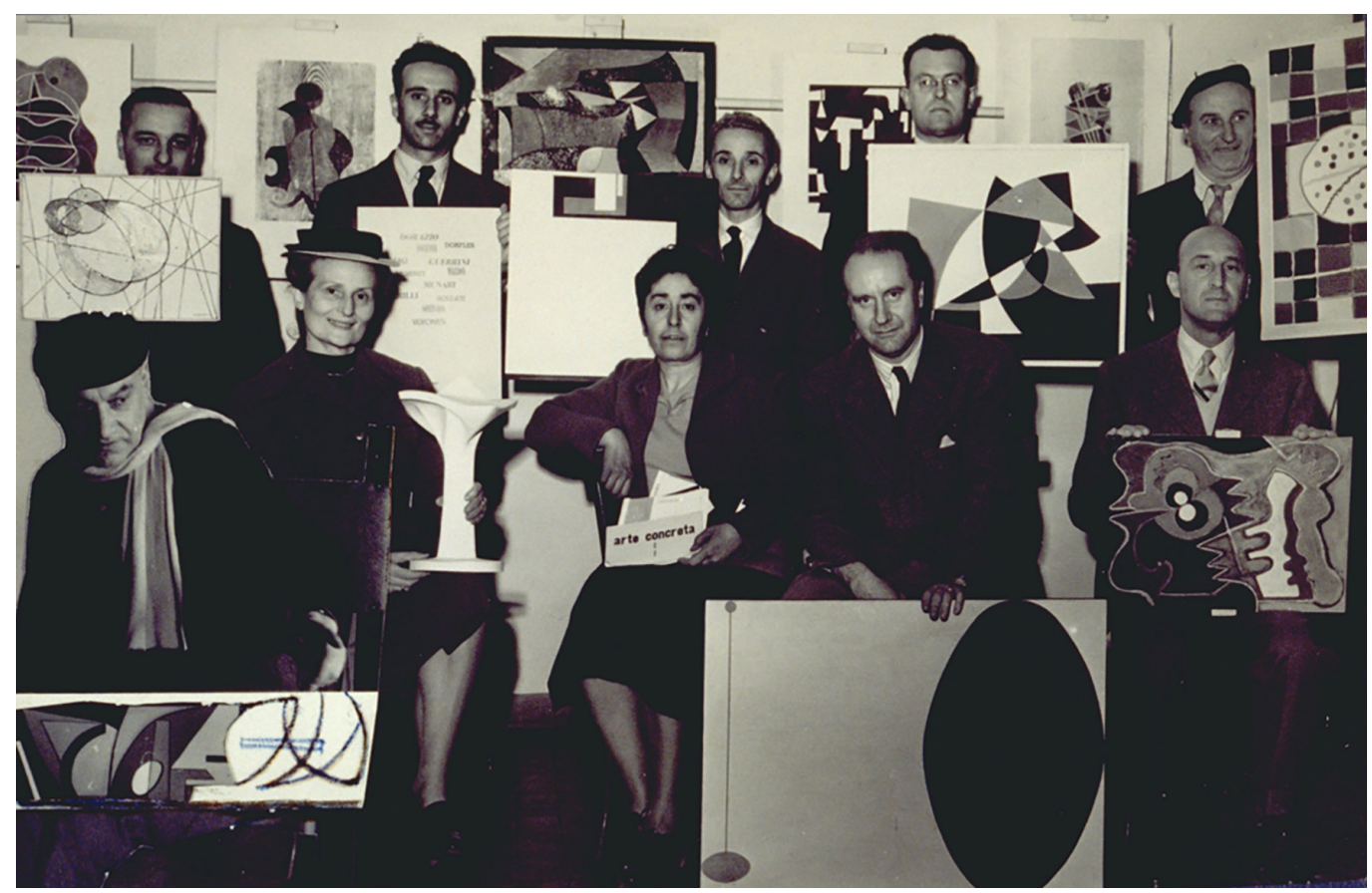




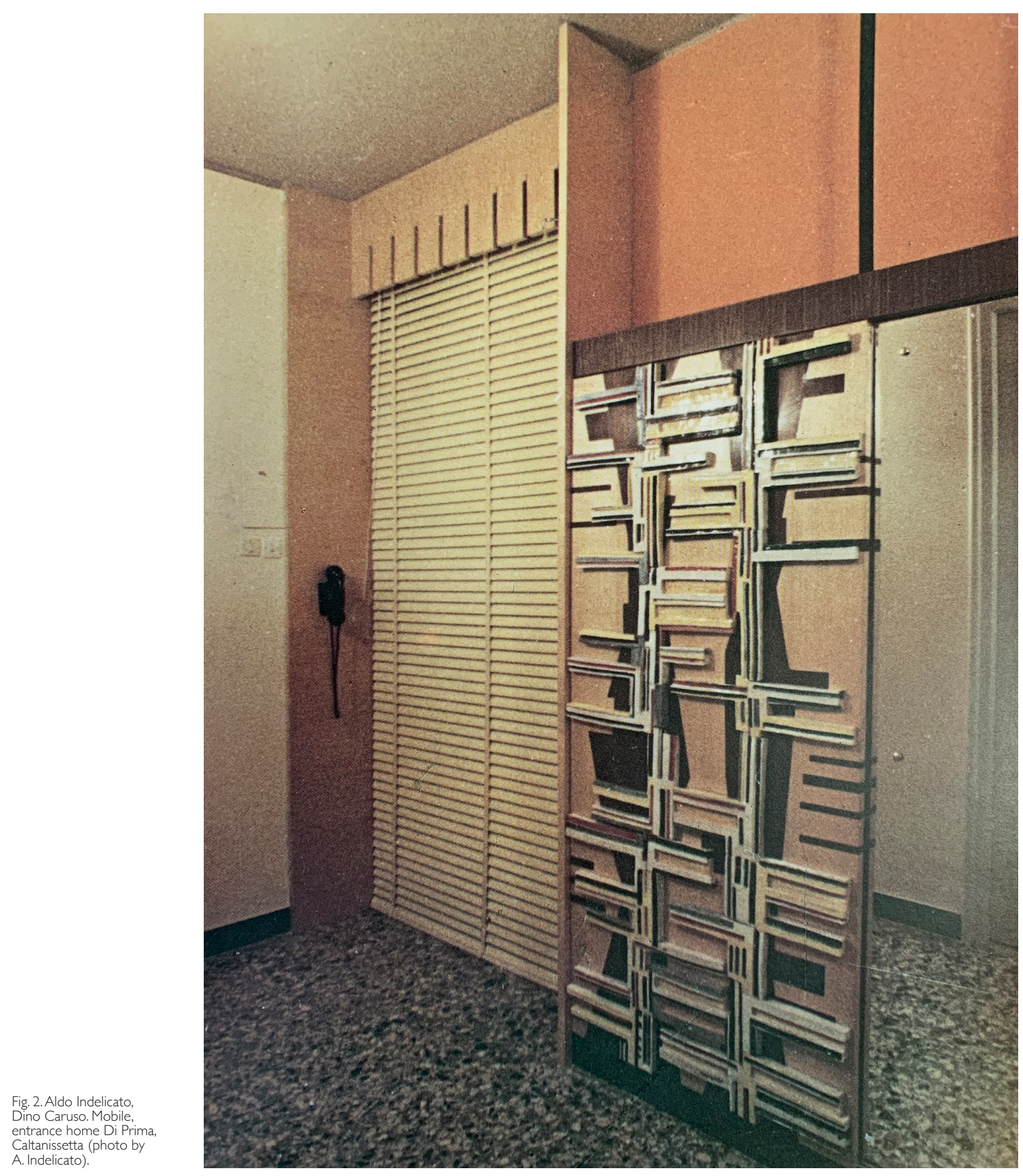


figures, squares, lozenges, triangles, or other signs, extrapolated also from the so-called decorative art and by the following development through chromaticism, the chromatic counterpoint, and the compositional rhythm, which comes to form the training center of the work of art [ I ].This search for formal purity is a new expressive language that blends architecture, painting and sculpture: the 'synthesis of the arts'. Carlo Perogalli, founder of MAC, in line with the definitions of Andrè Bloc of the Groupe Espace, speaks of an aspiration of the concrete art to the unitary expression, for which it is imperative that the artist interprets in himself the personalities of the architect, the sculptor, the painter [2], or, according to the definition of Franco Passoni, to be "il diretto concorso di tecnici e artisti, sul piano della stretta collaborazione, per il raggiungimento di un Concreto il quale aderisce alla Funzione in armonia e colleganza tra il mondo della forma, lo spazio nell'applicazione pratica dell'opera collettiva" [Indelicato Aldo 1998, p. 14] [3]. Same as in Liberty, this mixture also involves the applied arts, ceramics, plastics, graphics, weaving, set-up, but while in the floral style, architecture and decoration remains untied, in the MAC, the applied art, in competition with the three major arts, contributes to the creation of the unitary body of the total work. The function of synthesis between artist and crafts that had only been temporarily interrupted, on one hand, while on the other develops the figure of the designer formulated by Munari, intimately linked, more than to the figure of the artist, to that of the architect, since it is more pragmatic to and open to the technological innovation.




In the second phase of its existence, in 1955, the MAC will join, as an Italian concretist movement, with the French Groupe Espace with the aim of expanding the discourse of total art to an area and wider cultural implications. The parable of the MAC will be short and will end in 1958, but its influence will remain tangible in the developments of later art.

\section{The Sicilian MAC}

Extending in a few years to the whole Italian peninsula, Concreta Art landed in Sicily for a very short phase, from 1953 to 1958, constituting itself as MAC of Catania, although at first it also includes Palermo. The group is led by Gesualdo (Dino) Caruso, sculptor, painter and ceramicist originally from Caltagirone, who had frequented the study of the friend Enrico Prampolini, during the years of his Roman stay, initiates contacts with Munari and Monnet, who soon insert it into the MAC. In facts, together with other Sicilian artists, Caruso joins in 1953 the exhibition of the MAC, Collection set in Studio b-24 in Milan and his works are published in the bulletin Concrete Art together with those of Mirone, Santonocito, Signorelli and Teghini. Architects Aldo Indelicato and Corrado D'Urso and engineer Salvatore Costa join this group. The MAC of Catania is soon after present at the exhibition of MAC/Espace, at the gallery of the Fiore in Milan in 1955 and the other activities of the national group, in addition to carrying out exhibitions at the local level, until the last exhibition in 1957 at the Schettini gallery in Milan, the latter limited to the presence of the founder Caruso. Those who more than others understood and carried on the demands of the MAC were, besides Caruso, the painter Michele Santonocito and the architect Aldo Indelicato, to whom Caruso himself will constitute a close-knit artistic partnership (fig. 2).

The Sicilian MAC is located in an ideal continuity with the Sicilian Futurist movement both for its opposition to figurative, and for the rediscovery of craftsmanship [4]. In the case of the quality of architecture and in particular the experimentation of a synthesis of the arts that can be an opportunity for new urban signs, in which the taste for design is sublimating in the synthesis of formal technological aspects and in the pleasure of the project that is a vehicle for the art and creative culture of the places.






\section{The Connection of the Arts by Aldo Indelicato}

Aldo Indelicato was born in Messina in 1927, studying architecture with Roberto Pane and Ludovico Quaroni in the faculties of Venice and Naples, where he graduated in 1952. In his long professional activity he collaborates with leading figures of contemporary architecture such as Rovigo, Quaroni, Scarpa and Calandra. With Giuseppe Samonà he starts a collaboration that lasts years and that sees him cooperate in the construction of several buildings of the palatial of Messina. It dates back to 1953, immediately after graduation, the adhesion to the Sicilian MAC together with Michele Santonocito and Dino Caruso. With the latter he forms a partnership that will give life to several projects: a villa in Sant'Alessio, in the province of Messina, the palace of piazza Santa Maria di Gesù in Catania and the cinema Metropol of Messina.

Indelicato is a refined interpreter and open to the most advanced European currents of contemporary art and his architectures are symbolic works of that formal purism that underlies the 'synthesis of the arts' (fig. 3). For Indelicato the work comes from a vision that is both material, plastic, pictorial that becomes space and architectural form, far from decorativism, experimenting with new solutions, both on the level of the use of the form-space, and on the level of the structure-decoration relationship of the interior architecture [5]. In the experience with MAC, Indelicato has very clear ideas about the meaning of concretism and total work: his collaboration with Caruso is structured in this area with the main intent to pursue a synthesis between architectural project and applied arts, in the recovery of the craftsmanship of ceramic, plastic and pictorial art [6]. In this path he stands in continuity with a solid tradition that, in Messina, linked architecture to craftsmanship and that passed from the Royal School of Art and Crafts, which at the turn of the 1800s and 1900s assimilated the transition to Liberty, to the schools of applied art formed in Sicily with futurism, whose

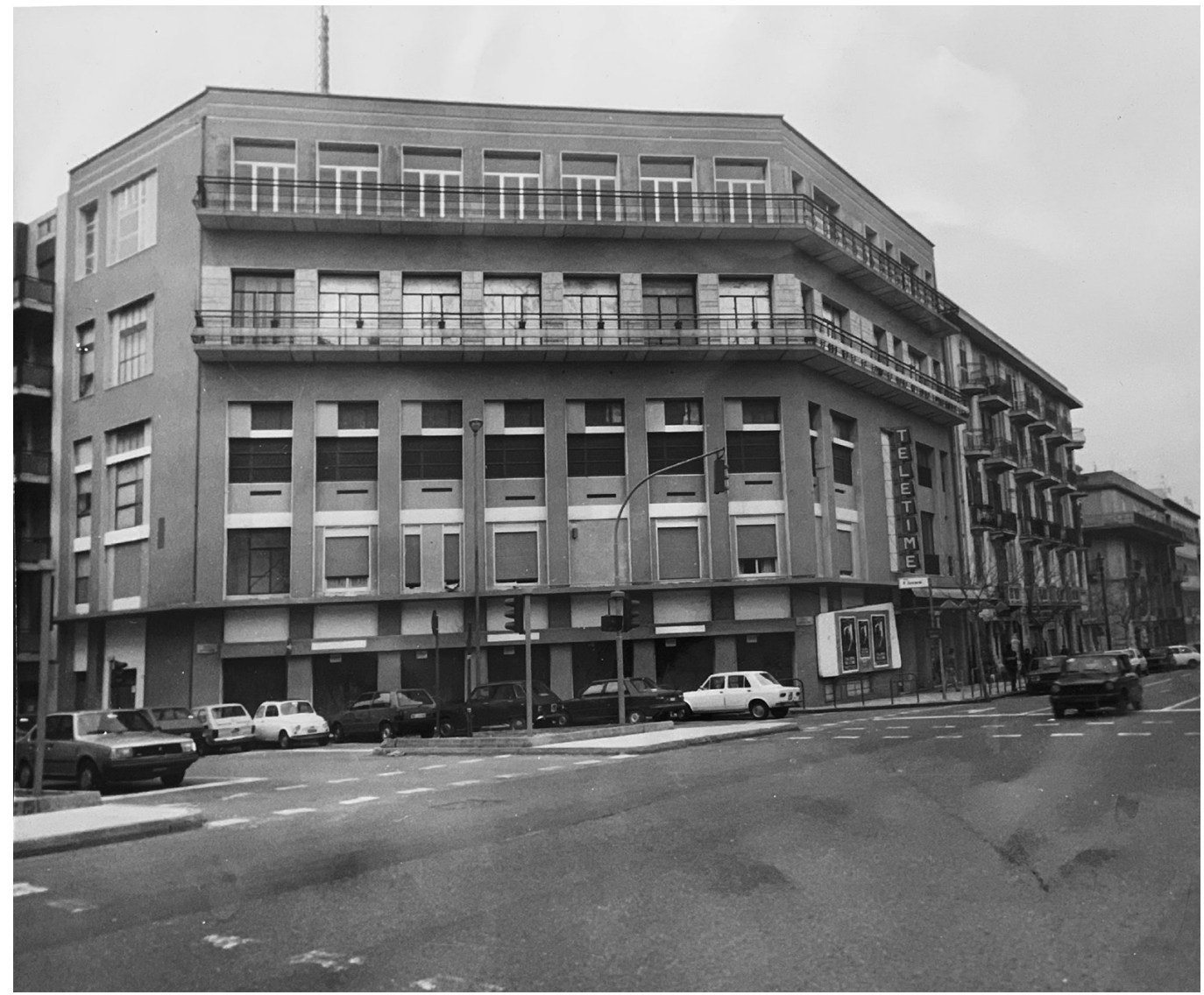


global interests involved ceramics, painting and tapestry. In this year he tends to re-propose the role of 'master of art', more than the figure of the designer and critically states: "Munari - and those who had a similar way of critically and operationally setting the synthesis of the arts, tending to the 'total art' - were convinced that the operator most intimately linked to the world of the architect is the designer and not the artist" [Sartori 1998, p. 12] [7]. It could be said that between the two souls of MAC, the artistic one, linked to the abstraction and the irrationality of art, which refers to Prampolini, and the other most intimately linked to the architecture and the figure of the designer, so dear to Munari, Indelicato, although approaching the scope of the latter, it seems to choose a third way, the one of the artisan architect. His work is thus placed in a dimension that is both design and artistic, which will have a final design cue in the experimental house, made in collaboration with Ravegnani, Vincenti and Brunori.

Even after the dissolution of the MAC, Indelicato will remain involved in the artistic vision promulgated by the group [8], which leads him to undertake in his works, close collaborations with other Sicilian artists such as Felice Canonico, Francesco Finocchiaro, Vincenzo Cacopardo, Mario Lucerne, the master craftsman Leuzzi. The combination of design and craftsmanship will also be the basis of the birth in 1954 of the Institute Statale d'Arte in Messina, founded by Salvatore Castagna, who directs between 1967 and 1983 and with the contribution of which will carry out several exhibitions on the design.

\section{The Metropol cinema, an example of a synthesis of the arts}

The intervention on the Metropol cinema in Messina, made in 1956, is part of those dictates of synthesis of the arts desired by the MAC, combining the architecture of Aldo Indelicato with the sculpture of Dino Caruso.

The project of cinema present in the archives of the Municipality of Messina in the file 191/1 for the company Cinema Fata Morgana, is signed by ing. Antonio Saccà and approved by

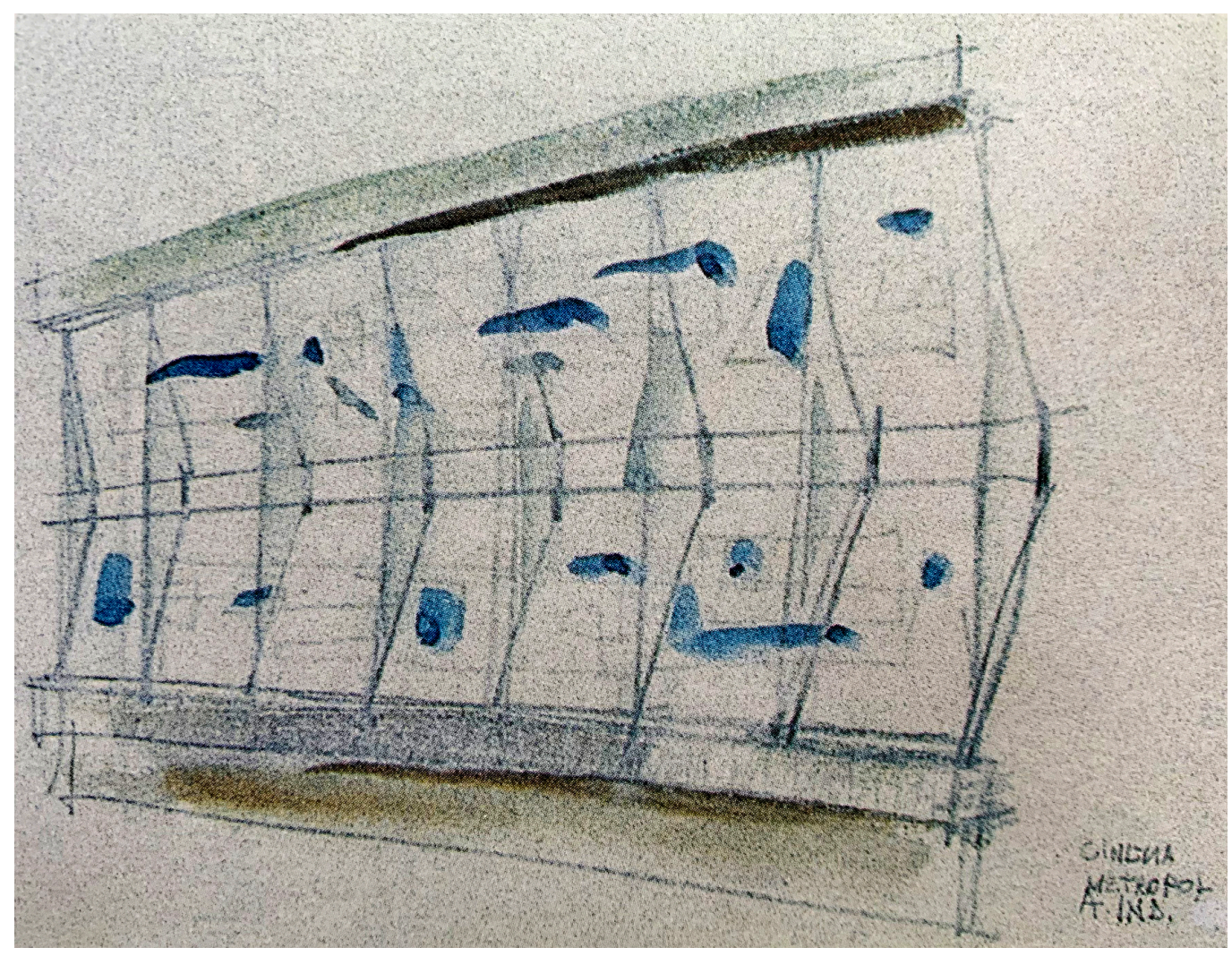







the Construction Commission in 1954 (fig. 4). Located on one of the sides that permeate piazza Juvara, the ancient piazza Octagona of which it kept its imprint, the project of the cinema involves the suppression of the original residential particle and the replacement with a building of five floors above ground, which breaks the unit skyline of the square. On the outside, the formal purity of the facade brings back to abstract and rigorous forms, carved vertically by the insertion of double-height holes, at the cinema grandstand, while the horizontal signs are underlined by the chiaroscural effect of the frame attached to the first level, by the two continuous balconies on two of the three external sides, placed on the fourth and fifth levels and by the artificial stone crowning (fig. 5).

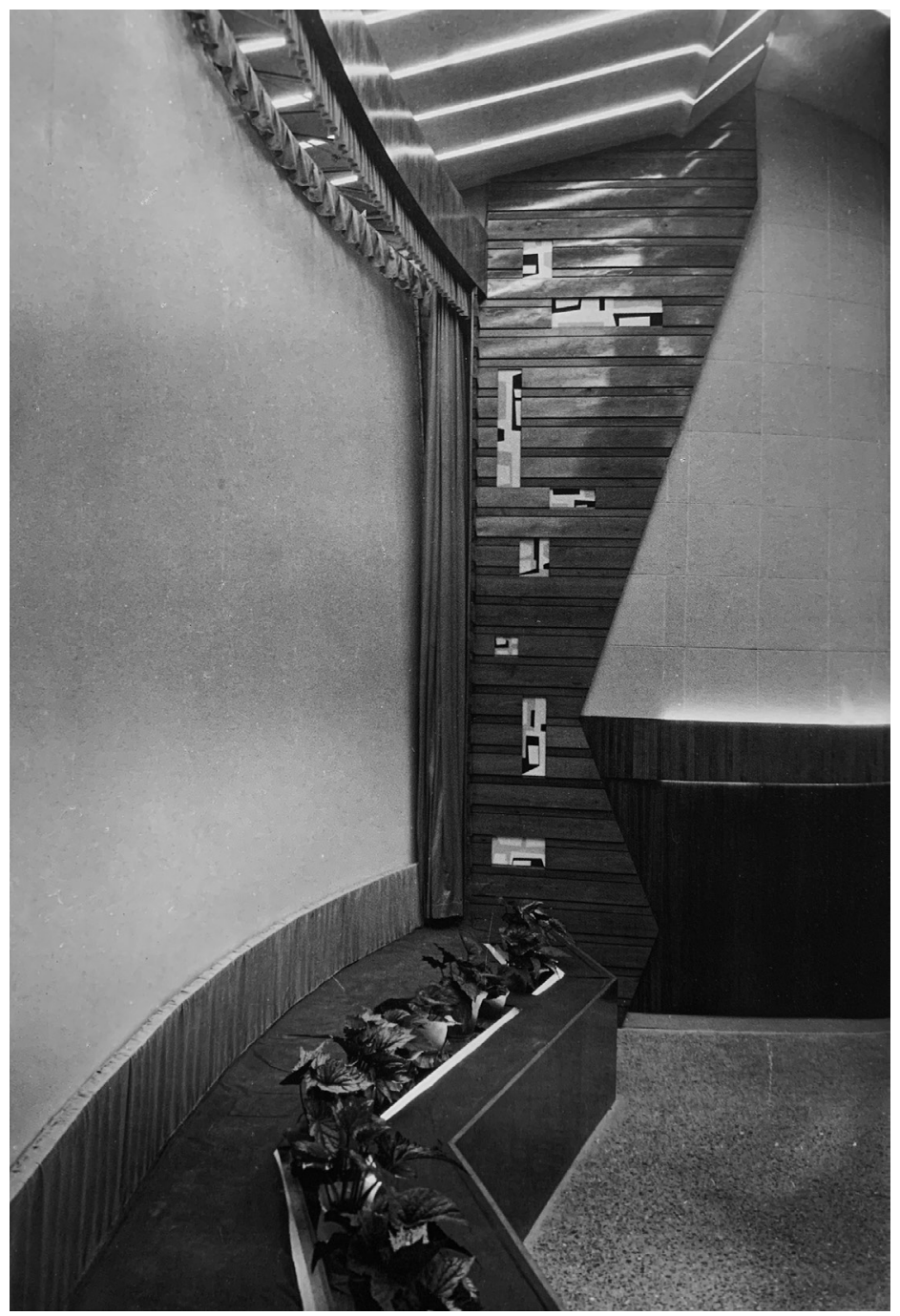

The intervention of Indelicato and Caruso in the interior of the building, creates an artistic synthesis that seems to contradict the rigor of the exterior, accentuated by the dynamism of the trapezoidal form of the plant. The combination of architecture, painting and sculpture, here also involves the applied art that permeates the interiors of the cinema, finding the highest peaks of artistic-architectural expression, in the counter-ceiling solutions of the entrance and the wooden one of the grandstand, in the volume decoration of the cabin and in the side area of the screen (figs. 6-9). Dino Caruso realizes the decorations of the grandstand and the ceramic inserts on the sides of the screen, without neglecting the de- 
Fig. 9. Aldo Indelicato, Dino Caruso, grandstand and screening booth of the Metropol cinema, Messina (photo by A. Indelicato).

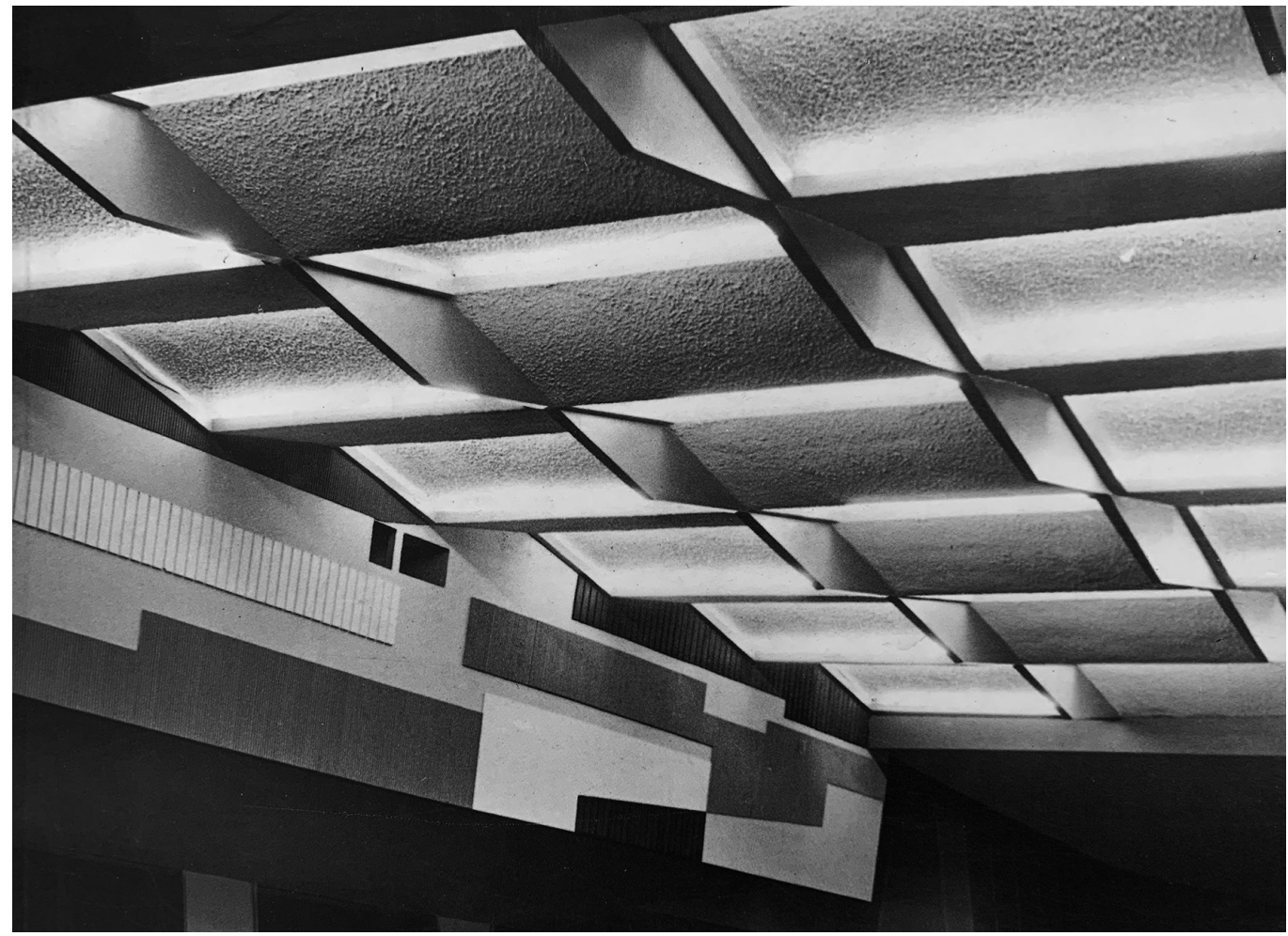

corative applications on doors, stairs and walls (fig. I0). Indelicato himself is aware that "the continuing decorative role of Caruso's interventions [...] consciously experimented with solutions that differed from the dictates of 'total architecture' [9].

From the designs for the grandstand we highlight the modus operandi of Aldo Indelicato, which starting from geometrically rigorous shapes, rendered in concrete images of shape-color, aims to capture rhythms, cadences and chromatic chords, which turn into dynamic and plastic signs (fig. I I). The project played between the formal purity of the exterior and the internal rhythm, manages to combine the themes of total art and the synthesis of the arts, so dear to the MAC.

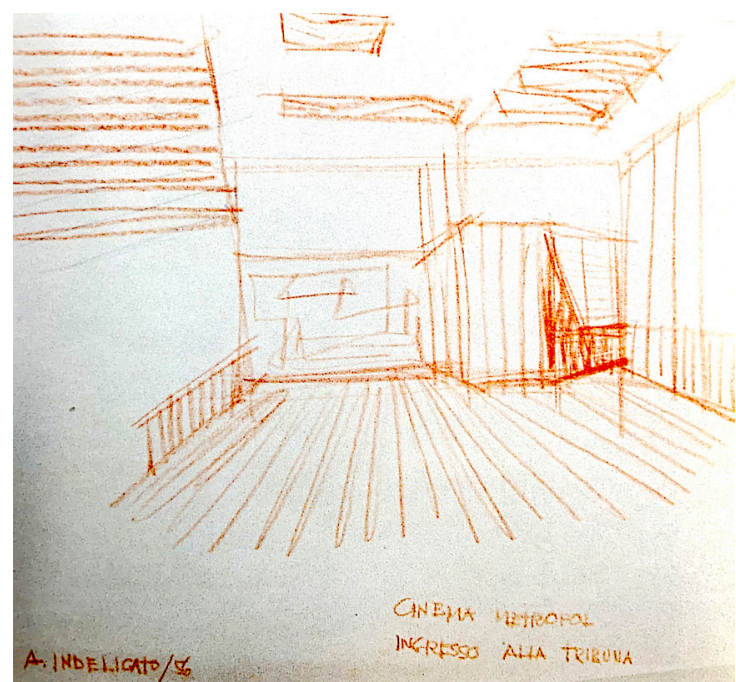




\section{Notes}

[I] Genoa Giorgio (1999). Concrete art and the utopia of the synthesis of the arts in France and Italy. In Berni Canani, Di Genoa 1999, p. 24.

[2] Carlo Perogalli, architect of the MAC, writes "where architecture, painting, sculpture are no longer distinguishable as elements juxtaposed, superimposed, summed, but where they materialize in unitary expression". For much to the his realization will require a single "artist that mimics the personalities of the architect, the sculptor, the painter, or the intimate collaboration of multiple artists": Caterina Sartori (1998). "The M.A.C." Order of architects of the province of Messina (ed.). Architettura e design nell'area dello Stretto. Spunti di ricerca, p. 14.

[3] "the direct competition of technicians and artists, on the level of close collaboration, for the achievement of a Concrete that adheres to the Function in harmony and interconnecting between the world of form, space in the practical application of the collective work". In Indelicato Aldo, 1998. Materiali per la storia del M.A.C. siciliano. On Dorfles G, Indelicate A. (catalogue edited by), 1998. II MAC siciliano e la sintesi delle arti, p. 14.

[4] Berni Canani Luciano (ed.). (1999). Intervista ad Aldo Indelicato. On MAC/Espace: arte concreta in Italia e in Francia, p. 49.

[5] Romeo Carmelo (1998). Aldo Indelicato: un percorso tra design e sintesi delle arti. On Architettura e design nell'area dello Stretto. Spunti di ricerca, p. 23.

[6] Genoa Giorgio (1999). La propaggine di Catania. On MAC/Espace: arte concreta in Italia e in Francia, p. I02.

[7] Sartori Caterina ( 1998). The M.A.C. On Architettura e design nell'area dello Stretto. Spunti di ricerca p. I2.

[8] Indelicato Aldo (1998). Materiali per la storia del M.A.C. siciliano. On Dorfles G., Indelicato A. (catalogue edited by), I998. II MAC siciliano e la sintesi delle arti, p. 9.

[9] Berni Canani Luciano (ed.). ( 1999). Intervista ad Aldo Indelicato. On MAC/Espace: arte concreta in Italia e in Francia, p. 49.

\section{References}

Berni Canani Luciano, Di Genova Giorgio (a cura di). (1999). MAC/Espace: arte concreta in Italia e in Francia 1948-1958. Bologna: Bora.

Cucinotta Francesca (20I I). Suggestioni sintetiste a Messina negli anni cinquanta e sessanta: dal MAC a Felice Canonico. In Città \& Territorio, 5, pp. 36-4l.

Dorfles Gillo, Indelicato Aldo (a cura di). (1998). Il MAC siciliano e la sintesi delle arti. Messina: Cartescritture.

Dorfles Gillo (2003). Ultime tendenze dell'arte d'oggi. Milano: Feltrinelli.

Indelicato Aldo (1999). Architettura e dintorni: spunti per una riflessione sulla "Sintesi delle Arti" nella città di Messina. In Città \& Territorio, I, pp. 46-50.

Indelicato Aldo (200 I). Decadenza e risveglio delle Arti applicate a Messina. In Città \& Territorio, 6, pp. 34-37.

Ordine degli Architetti della Provincia di Messina (a cura di). (1998). Architettura e design nell'area dello Stretto. Spunti di ricerca. Messina: Ordine Architetti Messina.

\section{Author}

Michela De Domenico, Università di Messina, micheladedomenico@gmail.com

To cite this chapter. De Domenico Michela (2020). Aldo Indelicato, il M.A.C. siciliano e la connessione tra le arti/Aldo Indelicato, the Sicilian M.A.C. and the Connection between the Arts In Arena A., Arena M., Brandolino R.G., Colistra D., Ginex G., Mediati D., Nucifora S., Raffa P. (a cura di) Connettere. Un disegno per annodare e tessere. Atti del $42^{\circ}$ Convegno Internazionale dei Docenti delle Discipline della Rappresentazione/Connecting. Drawing for weaving relationships. Proceedings of the 42th International Conference of Representation Disciplines Teachers. Milano: FrancoAngeli, pp. 368-389. 